Klaudia KAŁAZŻNA, Remigiusz ROSICKI

Poznań

\title{
O interesie narodowym i racji stanu - rozważania teoretyczne
}

\section{Wprowadzenie}

$I^{\text {nos }}$ nteres narodowy zestawiany jest z takimi pojęciami, jak potrzeby, cele, priorytety, preferencje oraz wartości, którymi kieruje się państwo. Ogólne pojęcie zawiera zatem wiele wątków, co utrudnia jego definicję. Obok tej kategorii funkcjonuje również pojęcie racji stanu. Racja stanu (fr. raison d'état, łac. ratio status) w powszechnym rozumieniu oznacza m.in. nadrzędny interes państwowy, wyższość interesu państwa nad innymi interesami i normami ${ }^{1}$. Obecne rozumienie tego pojęcia należy wiązać z rozwojem myśli politycznej i prawnej, a szczególnie ze sposobem definiowania państwa w okresie emancypacji państw od wpływu Kościoła. Nie bez znaczenia są też rozważania o państwie N. Machiavellego i F. Guicciardiniego, jednakże oni nie posługiwali się pojęciem racji stanu, a raczej pojęciem necessita - czyli koniecznością ${ }^{2}$. Słowa Machiavellego zawarte w Rozważaniach nad pierwszym dziesięcioksięgiem historii Rzymu Liwiusza traktuje się, jako punkt wyjścia dla definicji racji stanu: Kiedy chodzi bowiem o ocalenie ojczyzny, nie wolno kierować się tym, co słuszne lub niesłuszne, litościwe lub okrutne, chwalebne lub sromotne. Nad wszystko inne zważać należy wtedy na to, aby zapewnić jej przetrwanie i uratować jej wolność ${ }^{3}$.

\section{Racja stanu i interes narodowy}

Uważa się, że pojęcie racji stanu pierwszy raz zastosował włoski pisarz polityczny i historyczny G. Botero, pisząc książkę O racji stanu (Della Ragion di Stato) w XVI wieku, a na grunt francuski zostało ono zaadoptowane przez współpracownika kardynała Richelieu - C. Le Breta ${ }^{4}$. W. Buchner wskazuje, że myśl G. Botero wpisała się w ówczesny alians interesów monarchii Habsburgów i świata katolickiego. Według G. Botero racja stanu to zastosowanie koniecznych środków do wprowadzenia i rozszerzenia panowania nad narodami. Pomocne było to m.in. w uzasadnieniu obecności Habsburgów w Italii. Jakkolwiek dla jednych myślicieli obecność Habsburgów była wyznacznikiem dobra publicznego, to dla innych mogła stanowić zagrożenie dla racji stanu własnych państw. Na przykład, dla Republiki We-

\footnotetext{
${ }^{1}$ Stownik wyrazów obcych, Warszawa 1995, s. 929.

${ }^{2}$ F. Guicciardini, The History of Italy, Princeton 1984; N. Machiavelli, Ksiażę, Kraków 2006; J. M. Parent, Machiavelli's Missing Romulus and the Murderous Intent of The Prince, „History of Political Thought” 2005, nr 4 (vol. XXVI), s. 1-21.

${ }^{3}$ N. Machiavelli, Rozważania, w: Wybór pism, Warszawa 1972, s. 612.

${ }^{4}$ J. Malarczyk, ,, Racja stanu” w ujęciu Giovanniego Botero, w: Problemy teorii i filozofii prawa, red. J. Malarczyk, Lublin 1985, s. 161-172.
} 
neckiej ekspansja terytorialna monarchii habsburskiej stanowiła zagrożenie jej istnienia i niezależności - na co wskazywał m.in. T. Boccalini ${ }^{5}$.

Często politykę „lwa i lisa” N. Machiavelliego określa się mianem niemoralnej, jednakże należy wpisać ją w kontekst ówczesnej polityki europejskiej, gdzie nawet teologia służyła określonym interesom. Pod tym względem niemoralność nie była właściwością pism N. Machiavelliego (i jego naśladowców), a raczej praktyki politycznej w różnych wymiarach ówczesnej rzeczywistości. Krytyka N. Machiavelliego wynikała również z dyskusji religijnej, a ta opierała determinizm życia ludzkiego na woli boskiej. Można zadać sobie pytanie czym był swoisty fatalizm, wyrażany przez wolę boska, wobec ludzkiego virtù? W tym kontekście przyjaciel I. Loyoli, P. de Ribadeneyera napisał w swoim traktacie o religii i obowiązkach władcy: Politycy i uczniowie Machiavellego nie znaja żadnej religii, ani też nie zastanawiaja się nad jej fatszywościa czy prawdziwościa, jeśli nie stuży ona ich racji stanu. W ten sposób heretycy niszcza jakaśs część religii, politycy zaś - cała religię. Heretycy sa jawnymi nieprzyjaciótmi Kościoła katolickiego - i przed takimi winniśmy się mieć na baczności; atoli politycy sq fałszywymi przyjaciółmi, ale też prawdziwymi i rodzimymi wrogami, którzy kłamliwym pocałunkiem pokoju zabijajq niczym Judasz, a odziani w skórę owcy rozpraszajajak wilki trzodę Pańskq i pod nazwq i maska katolików wykorzeniaja, niszczq i rujnuja katolicka wiarę .

A. Rzegocki wskazuje, że samo pojęcie racji stanu zmieniało swoje znaczenie z kolejnymi wiekami. I tak w wieku XVI i XVII racja stanu wykorzystywana była do uzasadnienia próby emancypacji różnych podmiotów politycznych (księstw, królestw itd.) i konsolidacji narodowych tworów, natomiast w okresie państw absolutystycznych stała się paradygmatem prowadzonej polityki zewnętrznej. W XIX wieku racja stanu pomocna była w przywracaniu do życia podmiotowości narodów bezpaństwowych lub jednoczeniu narodów rozbitych ${ }^{7}$. A. Rzegocki wskazuje na anachroniczność pojęcia racji stanu w II połowie XX wieku, które utożsamione zostało w wielu państwach z władzą absolutną i nadrzędnością interesu państwa nad interesem obywateli ${ }^{8}$. O ile można się zgodzić z tymi ustaleniami, co do pojęcia racji stanu, to z taką samą stanowczością nie można powiedzieć tego samego o kategorii interesu narodowego.

A. Rzegocki wyróżnia tzw. dwie tradycje o myśleniu o ratio status - klasyczną i nowożytną. Klasyczna tradycja racji stanu opiera się szczególnie na dorobku intelektualnym starożytności i średniowiecza. Interes państwa i prawa państwowe zostają wmontowane w szerszą konstelację bytów, tzn. wpisują się w ład stworzony bądź to przez Boga, bądź to przez naturę. Natomiast tradycja nowożytna kształtowała się od XVI wieku. W tej tradycji interes państwa i jego prawa stały się dla władców ważniejsze niż inne byty i idee ${ }^{9}$. Oczywiście nie da się przedstawić ostrej granicy między tradycjami, można natomiast powiedzieć, że tradycje te wzajemnie się przenikały.

Obecnie samo pojęcie jest ujmowane i definiowane na wiele sposobów. Przykładowo Z. J. Pietraś dzieli pojęcie racji stanu na trzy grupy: uwzględniające bezwzględną wyższość interesu państwa nad innymi interesami i normami, uwzględniające względną wyższość interesu państwa nad innymi interesami i normami oraz uwzględniające autonomię interesu pań-

${ }^{5}$ W. Buchner, Wojna i konkwista. Hiszpańska myśl polityczna Złotego Wieku, Kraków 2007, s. 137-160.

${ }^{6}$ Cytat na podstawie: Tratado de la religión y virtudes que debetener el Príncipe christiano para gobernar y conservar sus Estados, contra lo que Nicolás Maquiavelo y los políticos de ese tiempo enseñan, Madrid 1595, w: W. Buchner, Wojna i konkwista. Hiszpańska myśl polityczna Złotego Wieku, Kraków 2007, s. 155.

${ }^{7}$ A. Rzegocki, Racja stanu a polska tradycja myślenia o polityce, Kraków 2008, s. 15-33.

${ }^{8}$ Ibidem, s. 17-18.

${ }^{9}$ Ibidem, 25-29. 
stwa nad normami moralnymi i prawnymi ${ }^{10}$. Natomiast Z. Rykiel utożsamia rację stanu z powodami istnienia państwa, czyli warunkami, z którymi wiąże się istnienie państwa. Państwo, tak jak w rozważaniach Arystotelesa, staje się samo w sobie dobrem - dobrem wspólnym $^{11}$. W tym wypadku racja stanu stanowi funkcję państwowości, ustroju i sytuacji geopolitycznej. Według Z. Rykiela istotnymi elementami racji stanu są: bezpieczeństwo, niepodległość, suwerenność oraz integralność terytorialna ${ }^{12}$. R. Kuźniar analizując ogólne pojęcie bezpieczeństwa, zwraca uwagę na różnicę między racją stanu a interesem narodowym, ale nie dokonuje klarownej demarkacji między tymi dwoma pojęciami. Pisze, iż można zatem powiedzieć, że bezpieczeństwo jest nieodtacznie zwiazane z żywotnymi (ważnymi dla życia) interesami narodowymi. Czasem określa się jako rację stanu, choć to pojęcie jest często nadużywane $w$ doraźnych celach politycznych i należy zachować ostrożność zarówno w postugiwaniu się nim, jak $i$ w jego recepcji $w$ różnych kontekstach ideowych i politycznych ${ }^{13}$.

Kategorię interesu narodowego należy ściśle wiązać ze sferą polityki. Interes narodowy jest priorytetem polityki zewnętrznej prowadzonej przez państwo. $Z$ jednej strony, ma on charakter postulatywny, tzn. umożliwia przedstawienie państwu (jego przedstawicielom) własnego stanowiska co do celów i wartości, jakie mają dla niego żywotne znaczenie, stąd mówi się o żywotnych interesach (vital interests). Z drugiej strony, stanowi on ramowy szkielet dla działań w zakresie realizacji określonych żywotnych interesów. Wyrazicielem interesu narodowego mogą być przedstawiciele państwa, jego organy, jak i samo społeczeństwo. Z założenia jednak, interes ma charakter powszechny i dotyczy w modelowym ujęciu wszystkich podmiotów w państwie. W przypadku interesu narodowego zakłada się świadomość priorytetowych celów, chęć ich realizacji, jak i ich manifestację wewnątrz państwa oraz w stosunkach między innymi państwami. K. Żukrowska pisze, że pojęcie to $w$ przeszłości oznaczało definiowanie interesu narodowego $w$ zgodzie $z$ autonomicznymi celami danego kraju. Obecnie w warunkach umiędzynarodowienia gospodarki $i$ występowania silnych więzi wspótzależności nie można decydować autonomicznie o interesie danego kraju. Rozmyly się bowiem granice między danym państwem a jego otoczeniem międzynarodowym [...] $W$ tym kontekście interesem każdego kraju staje się pogłębienie tych wspólzależności, które staja się samoczynnie gwarantem bezpieczeństwa pozamilitarnego danego kraju ${ }^{14}$.

V. Udalov rozważa interes narodowy na podstawie dwóch ujęć funkcjonujących wśród badaczy wywodzących się z państw z przeciwstawnych bloków podczas zimnej wojny - USA i ZSRR ${ }^{15}$. Według niego kategoria interesu narodowego u badaczy amerykańskich sprowadzona została do potrzeb, teleologicznych determinantów oraz niepoddających się negocjacji przyczyn ludzkich zachowań (na każdym poziomie od indywidualnego do międzynarodowego). Na interes składają się - w tych ujęciach - takie pojęcia, jak przetrwanie, bezpieczeństwo i tożsamość. Wynika z tego, że bezpieczeństwo jest jednym z głównych elementów interesu narodowego. Podejścia te jednak nie uwzględniały dynamiki procesu związanego z interesem narodowym, co więcej, wartościom nadano tutaj charakter autonomiczny w stosunku do po-

${ }^{10}$ Z. J. Pietraś, Racja stanu w polityce zagranicznej państwa, „Studia Nauk Politycznych” 1986, nr 5, s. 91-93.

${ }^{11}$ Arystoteles, Polityka, Warszawa 2008, s. 25-44 (Księga pierwsza).

12 Z. Rykiel, Podstawy geografii politycznej, Warszawa 2006, s. 37-38.

${ }^{13}$ R. Kuźniar, Bezpieczeństwo w stosunkach międzynarodowych, w: Stosunki międzynarodowe. Geneza, struktura, dynamika, red. E. Haliżak, R. Kuźniar, Warszawa 2006, s. 143.

${ }^{14}$ K. Żukrowska, Pojęcie bezpieczeństwa i jego ewolucja, w: Bezpieczeństwo międzynarodowe. Teoria i praktyka, red. K. Żukrowska, M. Grącik, Warszawa 2006, s. 36.

${ }^{15}$ V. Udalov, National Interests and Conflict Reduction, w: Cooperative Security. Reducing Third World Wars, red. I. W. Zartman, V. A. Kremenyuk, Seracuse New York 1995, s. 61-77. 
trzeb. W przypadku badaczy wywodzących się z ZSRR interes rozważany był jako podstawowy element motywacji, gdzie w centrum były ludzkie myślenie i działanie, które to formułują postawy, cele i intencje. Według V. Udalova to, co zarysowało pojęcie interesu w ujęciach amerykańskich, oprócz podejścia wyżej wspomnianego, sprowadzało się do następujących potrzeb - do tego, co ludzie chcą i o co się martwią oraz do tego, co ludzie mówią, że chcą.

W przypadku radzieckich ujęć, interes był traktowany jako główny element konstruowania polityki zagranicznej państwa, ale nie miał on charakteru autonomicznego, tzn. był on tylko jednym z ogniw w procesie podejmowania decyzji. Jeżeli chodzi o interes, to traktowany on był, jako pochodna potrzeb i skutek ich akceptacji. Pierwotność potrzeb w stosunku do interesu podkreśla również I. Popiuk-Rysińska ${ }^{16}$. O ile potrzebom przypisywano obiektywny charakter (obiektywna determinanta), o tyle interesowi subiektywny. Interes - jako składowa polityki - stawał na granicy pomiędzy subiektywnym namysłem przy podejmowaniu decyzji a obiektywną rzeczywistością. Wynika z tego, że sam fakt przypisania polityce interesu skutkował zaliczeniem go do zbioru o charakterze subiektywnym, a więc dopuszczano irracjonalność samego interesu narodowego. Podobne ujęcie interesów przedstawiał J. Kukułka, według którego były one forma wyrażania i ukierunkowania realizowanych potrzeb, a zarazem tworzq ogniwo łaczace owe potrzeby z celami narodów, państw czy ich grup kierowniczych. Dlatego interesy nosza zwykle subiektywne piętno wyrażajacych je podmiotów, które swoje oceny, wyobrażenia i aspiracje wiaża z określona rzeczywistościq. Subiektywna wola realizacji danego interesu prowadzi do formułowania celu aktywności podmiotu.

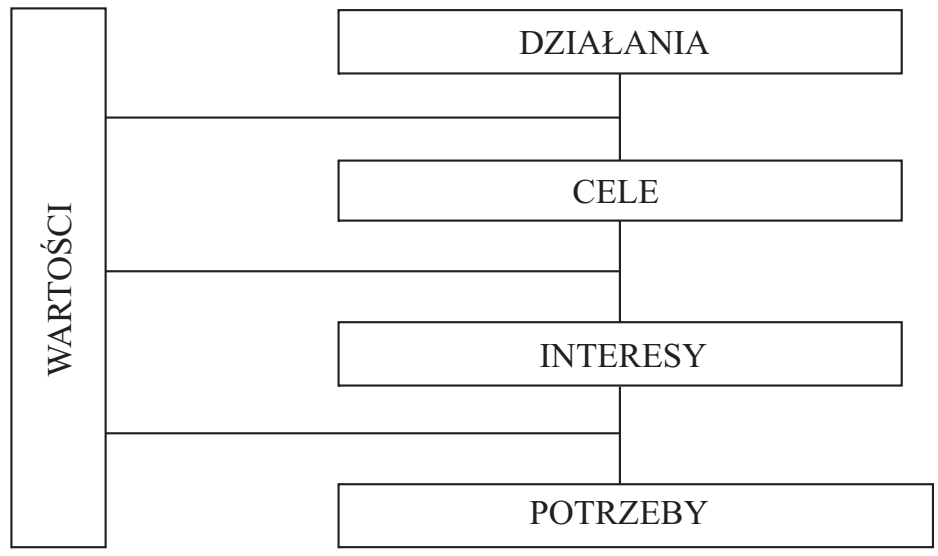

Rys. 1. Relacje między wartościami a działaniami, celami, interesami i potrzebami

Źródło: V. Udalov, National Interests and Conflict Reduction, w: Cooperative Security. Reducing Third World Wars, red. I. W. Zartman, V. A. Kremenyuk, Seracuse New York 1995, s. 64.

W ten sposób wspótzależność potrzeb, interesów i celów tworzy wewnętrzny mechanizm wszystkich procesów oddziaływań międzynarodowych ${ }^{17}$. W ujęciu J. Kukułki potrzeby mają

\footnotetext{
${ }^{16}$ I. Popiuk-Rysinska, Uczestnicy stosunków międzynarodowych, ich interesy i oddziaływania, w: Stosunki międzynarodowe. Geneza, struktura, dynamika, red. E. Haliżak, R. Kuźniar, Warszawa 2006, s. 107-108.

${ }^{17}$ J. Kukułka, Zaspokajanie potrzeb i rozwiazywanie konfliktów w stosunkach międzynarodowych, w: Stosunki międzynarodowe. Geneza, struktura, dynamika, red. E. Haliżak, R. Kuźniar, Warszawa 2006, s. 253.
} 
trzy wymiary, a nie tylko obiektywny, jak podkreślał to V. Udalov. Można wymienić następujące wymiary: potrzeba, jako obiektywna właściwość i niezbędny warunek, potrzeba, jako subiektywne odczucie określonego braku oraz potrzeba w znaczeniu realnym jako stan braku zaspokojenia warunków bytowania i rozwoju ${ }^{18}$.

W badaniach nad stosunkami międzynarodowymi, jak i nad samą polityką, ważną kategorią są wartości. Według V. Udalova wartości nie są w prosty sposób połączone z procesem tworzenia polityki. Według V. Udalova mają one charakter autonomicznego czynnika oddziaływania w procesie podejmowania działań politycznych (zob. rys. 1). Potrzeby, jak wspomniano wyżej, mają charakter obiektywny, a interes w procesie decyzyjnym polityki nabiera charakteru subiektywnego. Pomiędzy interesem a określonym działaniem politycznym nie można mówić tylko o jednym poziomie celów. Przykładowo jeżeli przyjmiemy, że głównym celem Rosji jest uzyskanie silniejszego wpływu na politykę międzynarodową i odbudowa swojej dawnej pozycji, to drugorzędnymi celami będą tutaj: osłabianie pozycji politycznej innych podmiotów, rozwój ekonomiczny, inwestycje w innych państwach itp. Przy takim założeniu interes można sprowadzić do ogólnych celów wraz z ich wewnętrzną złożonością, a pomiędzy poziomem interesu i celu można uwzględnić różnorakie motywacje.

I. Popiuk-Rysinska pisze, że interesy uczestników stosunków międzynarodowych są odzwierciedleniem ich wzajemnych relacji - zależności. Po pierwsze, określaja pożąane stany stosunków między uczestnikiem a jego środowiskiem. Ogólnie można powiedzieć, że chodzi o takie stosunki, które w maksymalnym stopniu zapewniaja przetrwanie i rozwój uczestników. Należa do nich interesy bezpieczeństwa, niezależności, tożsamości, uczestnictwa w życiu międzynarodowym, korzystnej wspótpracy międzynarodowej itp. Po drugie, interesy wyrażaja pożadane stany zjawisk i procesów międzynarodowych oraz środowiska międzynarodowego. Należy do nich zaliczyć interesy ochrony i umacniania pokoju, ochrony praw człowieka, rozwój handlu międzynarodowego, rozwój wspólpracy międzynarodowej, instytucjonalizację stosunków międzynarodowych [...] Po trzecie, interesy określaja pożq̨dane przez uczestników statusy, pozycje i role międzynarodowe ${ }^{19}$.

Na poziomie teoretycznym można dokonywać różnych demarkacji kategorialnych, problem jednak polega na tym, że polityka zagraniczna jest częścią składową polityki państwa, a ta jest prowadzona przez polityków, którzy nie posługują się klarownym językiem naukowym, co przysparza problemów w definiowaniu podstawowych pojęć. Przykładem może być przemówienie polskiego ministra spraw zagranicznych R. Sikorskiego określające priorytety polskiej polityki zagranicznej: Polityka zagraniczna, codzienna wspótpraca i konfrontacja państw $i$ narodów, a także splatanie się ich celów i interesów, jest jak lustro, w którym możemy się przegladać jako wspólnota. Widać w nim wielkość bąź małość, prestiż badź lekceważenie, rozwój lub upadek. Zmienność tych czynników w czasie ukazuje ską przyszliśmy, kim jesteśmy i co powinniśmy czynić, by umacniać Rzeczpospolita ${ }^{20}$.

W schemacie relacji między wartościami, działaniami, celami, interesami i potrzebami, według V. Udalova, założenia teoretyczne stanowiły, że interes jest pewnym elementem w całym procesie podejmowania decyzji politycznych, bezpośrednio określonym przez wyznaczone cele. Skutkiem takiego podejścia jest rozważanie i opis interesu poprzez cele przy analizie politycznych działań. Zauważyć należy, że każdy z celów może być związany z różną

\footnotetext{
${ }^{18}$ Ibidem, s. 252-253.

${ }^{19}$ I. Popiuk-Rysinska, Uczestnicy stosunków..., op. cit., s. 108.

${ }^{20}$ Informacja Ministra Spraw Zagranicznych nt. polityki zagranicznej RP w 2008 r. (wersja nieoparta na stenogramie sejmowym), http://www.msz.gov.pl/files/ExposeMinistraSikorskiego.doc, 7.08.2008.
} 
liczbą interesów w danym momencie. Szczegółowe określenie motywów usytuowanych pomiędzy celami a interesami zbliża je do celów, ich bardziej ogólne ujęcia każą rozpatrywać je jako interesy (ujęcie tradycyjne). Ostatnim ogniwem przedstawionych relacji są decyzje. Interes narodowy zatem, można określić jako coś, czym jest państwo, a raczej tym, jak zdefiniują go decydenci polityczni ${ }^{21}$. Przykładem może być wcześniej wspomniane przemówienie ministra R. Sikorskiego na temat polityki zagranicznej Polski, w którym przedstawia on własną definicję interesu narodowego odpowiadającej sytuacji politycznej ad hoc: Warto by więc może zastanowić się nad przekonujaca definicja ,, interesu narodowego" wspótczesnej Polski. Zapewne zgodzimy się, że najważniejsze jest to, aby nasz naród miał poczucie kontroli nad swoim losem. Ale nie wystarczy być wolnym - trzeba jeszcze umieć konkurować. A więc aby być, trzeba się umacniać. A umacnianie się to dorównywanie przez Polskę do poziomu rozwoju co najmniej naszego środowiska unijnego. Członkostwo Polski w Unii Europejskiej, inspiruje nas do dokonania skoku cywilizacyjnego. Taki rozwój cywilizacyjny bezwzględnie leży $w$ naszym interesie narodowym ${ }^{22}$.

W mechanizmie kształtowania decyzji politycznych, analizowanym przez V. Udalova, nie uwzględnia się wpływu opinii publicznej na decydentów i jej charakteru autonomicznego w stosunku do ich decyzji politycznych. Koncepcja ta skupia się na tradycyjnym ujmowaniu interesu narodowego jako interesu państwa. Należy jednak zauważyć, że przecież można abstrakcyjnie założyć sytuację, gdzie naród będzie przedstawiać inne interesy, które mogą być sprzeczne z działaniami politycznymi. Przykładem może być sprzeciw społeczeństwa amerykańskiego, co do uczestnictwa w wojnie wietnamskiej czy irackiej. Tak przedstawioną koncepcję interesu należałoby rozbudować o elementy wpływu społecznego, jak i możliwości kształtowania się interesu w świadomości narodu, nie tylko w aspekcie podejmowanych działań decydentów politycznych (zob. rys. 2). Takie rozszerzenie koncepcji interesu wykraczałoby poza tradycyjne definiowanie interesu narodowego jako interesu państwa. Węższe koncepcje pojęcia interesu narodowego mogą wynikać z problemu tłumaczenia słowa national, które oznacza w języku angielskim również państwowy, krajowy i narodowy. Ponadto ujęcie tradycyjne jest konsekwencją procesu historycznego kształtowania się państwa, a więc i teoretycznych rozważań na ten temat. W koncepcjach części autorów kształtowanie się państwa wiązane jest z budową państwa narodowego jako koherentnej struktury. Na przykład ujęcie modernistyczne P. J. Taylora i C. Flinta opiera się na założeniu, że kształtowanie się narodu związane jest z oddziaływaniem struktur państwowych, tzn. że naród jest wytworem państwa (państwo ,produkuje” naród) ${ }^{23}$.

Niektórzy autorzy przedstawiają definicję interesu narodowego, utożsamiając jego zakres przedmiotowy tylko z narodem. Przykładowo Z. Rykiel próbując zarysować różnicę między racją stanu a interesem narodowym pisze, że racji stanu nie należy mylić z interesem narodowym, ponieważ państwo nie jest tożsame z narodem. Interes narodowy można określić jako dobro nieco niższego rzędu niż racja stanu. W przeciwieństwie do tej ostatniej, interes narodowy jest zazwyczaj zwiazany z interesem obywateli, nie musi być natomiast zbieżny z racja $\operatorname{stanu}^{24}$. Natomiast G. Modelski stara się nie używać w ogóle pojęcia interesu narodowego, bowiem nie ma ono, jego zdaniem, czytelnego charakteru. Według niego kategoria ta sugero-

${ }^{21}$ E. S. Furniss, R. C. Snyder, An Introduction to American Foreign Policy, Rinehard, New York 1955, s. 17.

${ }^{22}$ Informacja Ministra Spraw Zagranicznych nt. polityki zagranicznej RP w 2008 r. (wersja nieoparta na stenogramie sejmowym), http://www.msz.gov.pl/files/ExposeMinistraSikorskiego.doc, 7.08.2008.

${ }^{23}$ P. J. Taylor, C. Flint, Political Geography, Edinburgh 2000, s. 193-234.

${ }^{24}$ Z. Rykiel, Podstawy geografii politycznej, Warszawa 2006, s. 37. 
wałaby istnienie koherentnej wspólnoty narodowej o wspólnym interesie, co wydaje się niemożliwe $\mathrm{z}$ racji wielości interesów wysuwanych przez różne grupy w ramach państwa ${ }^{25}$. Dlatego J. Kukułka, analizując mechanizmy zaspakajania potrzeb i rozwiązywania konfliktów, posługuje się bardziej bezpiecznymi pojęciami, czyli interesami i celami egzystencjalnymi (żywotnymi), które związane są dla niego z trzema elementami definicyjnymi państwa: terytorium, ludnością, suwerenną władzą ${ }^{26}$. Elementy te można sprowadzić do całości interesów, problemów bezpieczeństwa, tożsamości, adaptacji, rozwoju itd. Oprócz interesów egzystencjalnych autor ten wymienił inne - koegzystencjalne i funkcjonalne ${ }^{27}$. Interesy koegzystencjalne dotyczą zarówno składników trójelementowej definicji państwa (są nimi przede wszystkim suwerenność, autonomiczność), jak i współdziałania, wzajemności i pozycji. Interesy funkcjonalne natomiast odnoszą się do działania państwa, czyli jego skuteczności, sprawności, jak i możliwości technologicznych, innowacyjnych i informacyjnych. Ostatnia funkcja umożliwia realizację dwóch pierwszych, a więc ma charakter operacyjny.

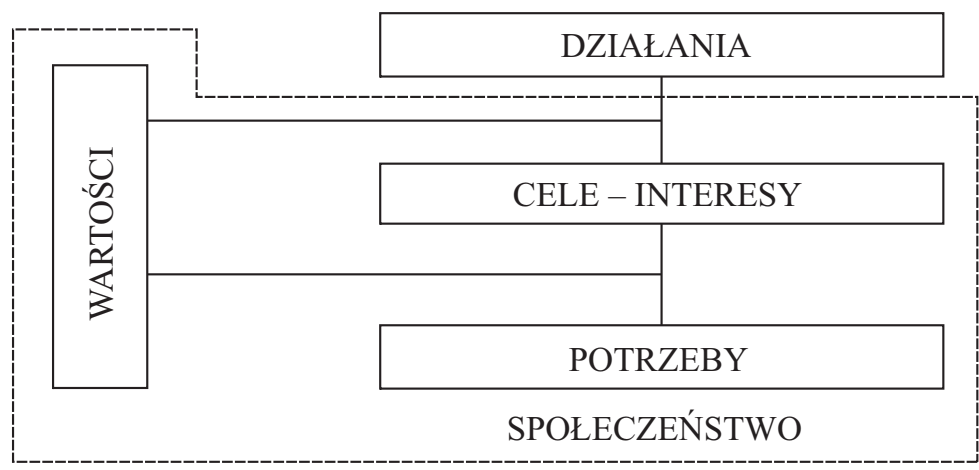

Rys. 2. Rozszerzona analiza interesu narodowego

Źródło: Opracowanie własne.

\section{Wladza a interes narodowy}

R. A. Dahl i B. Stinebrickner, analizując problematykę władzy, określili koncepcję władzy S. Lukesa jako relację, w której podmiot ją sprawujący wywiera wpływ na inny podmiot, w taki sposób, że jest on niezgodny z jego interesami ${ }^{28}$. Według tych autorów koncepcja J. Marcha ma charakter odwrotny, tzn. zakłada, że relacja władzy opiera się na możliwości wywierania wpływu na innych tak, by ci postępowali zgodnie z interesami, jakie ma posiadający władzę ${ }^{29}$. Można stwierdzić, że relacje władzy to nic innego, jak relacje odrębnych

${ }^{25}$ G. Modelski, A Theory of Foreign Policy, London 1962, s. 70-72.

${ }^{26}$ J. Kukułka, Zaspokajanie potrzeb i rozwiazywanie konfliktów w stosunkach międzynarodowych, w: Stosunki międzynarodowe..., op. cit., red. E. Haliżak, R. Kuźniar, Wyd. WUW, Warszawa 2006, s. 253.

${ }^{27}$ J. Kukułka, Problemy teorii stosunków międzynarodowych, Warszawa 1978, s. 265.

${ }^{28}$ R. Dahl, B. Stinebrickner, Wspótczesna analiza polityczna, Warszawa 2007, s. 33; S. Lukes, Władza i panowanie, w: Socjologia. Lektury, red. P. Sztompka, M. Kucia, Kraków 2007, s. 492-503; S. Lukes, Władza: poglad radykalny, „Poznańskie Studia z Filozofii Humanistyki” 1997, t. 4 (17), s. 295-306.

${ }^{29}$ R. Dahl, B. Stinebrickner, Współczesna analiza..., op. cit., s. 34; J. C. March, Preferences, Power and Democracy, w: Power, Inequality and Democratic Politics, red. I. Shapiro, G. Reeher, Boulder, CO - London 1988, s. 51. 
interesów obu podmiotów stosunku władczego. Natomiast weberowska definicję władzy określa się mianem behawioralno-instrumentalnej. Pierwszy człon zakłada, że stosunek władzy ma charakter konfliktowy, bowiem opiera się na narzucaniu przez sprawującego władzę własnego interesu, który nie zawsze musi być tożsamy z interesem osób, na które on wpływa. Z drugiego elementu tej definicji wynika, że państwo posiada prawnie usankcjonowane środki przemocy, które umożliwiają realizację jego celów.

Prowadząc rozważania na temat władzy i interesu narodowego, pojawia się kolejne bardzo ważne pytanie: jak mają się rozważania na temat władzy do relacji międzynarodowych? Odpowiedź wydaje się oczywista: relacje siły o różnym charakterze w znacznym stopniu podobne są do relacji władzy, jednakże trzeba zaznaczyć, że na gruncie społeczności międzynarodowej mamy do czynienia z innym charakterem obiektów, co w konsekwencji rzutuje na opis tychże relacji. Relacje siły w społeczności międzynarodowej w swej podstawie mają różne interesy. Możemy, więc mówić o wykorzystywaniu różnie definiowanej siły do realizacji własnych interesów przez podmioty państwowe. Na tak kształtowane interesy narodowe mogą mieć wpływ interesy różnych grup nacisku (działających zarówno w skali globalnej, jak i lokalnej) i sama rywalizacja polityczna wewnątrz państwa, która przybiera postać różnych interesów politycznych. Różnorodność interesów po stronie wszystkich wymienionych podmiotów wykazuje, że relacje między nimi muszą charakteryzować się pewnym poziomem konfliktowości. Tak jak dla K. Marksa kategoria interesu była punktem wyjścia dla analizy dynamiki zmian społecznych ${ }^{30}$, tak wydaje się słuszne przyjęcie, że procesy kształtowania się interesów narodowych mają charakter konfliktowy. Należy wskazać, że na kształtowanie się interesu narodowego wpływ mają interesy różnych grup nacisków, interesy polityczne i obiektywne potrzeby państwa. Wszystko to wpływa na określenie celów działań, a te z kolei podejmowane są podczas danych działań i decyzji politycznych w tym zakresie.

Należy zwrócić uwagę na to, co podkreślał V. Udalov, że interesy w stosunku do potrzeb mają charakter subiektywny, co wynikać może z wymienionych elementów, które składają się na zaprezentowaną propozycję procesu budowania interesu narodowego. Ponadto dużym stopniem subiektywności będą się cechować interesy polityczne, które charakteryzują polityczną sytuację w państwie.

\section{Zakończenie}

Pojęcia racji stanu i interesu narodowego pojawiają się w dyskusji na szczeblu międzynarodowym, jak i w wewnętrznej polityce. Mimo dynamicznego rozwoju procesów globalizacji oraz transformacji tradycyjnej polityki wewnętrznej (np. zjawisko postpolityki) należy podkreślić, że kategorie racji stanu i interesu narodowego w dalszym ciagu stanowią istotny wyznacznik retoryki politycznej. Wynika to z praktyczności wyżej wspomnianych kategorii w prowadzeniu polityki zagranicznej oraz polityki na szczeblu krajowym. Bezpośrednie odwołanie się do interesu narodowego stanowi ważny argument w dyskusji politycznej. Efektem tego jest skuteczne zablokowanie wszelkiej kolejnej argumentacji, bowiem interes narodowy ma być priorytetem dla polityki i państwa. Zarzut postępowania przeciw interesowi narodowemu stanowi zatem jednocześnie zarzut działania na niekorzyść społeczeństwa. Po-

\footnotetext{
${ }^{30}$ L. Sobkowiak, Konflikt polityczny-analiza pojęcia, w: A. W. Jabłoński, L. Sobkowiak, Studia z teorii polityki, t. 1, Wrocław 1998, s. 118-119.
} 
nadto obie kategorie nie należą tylko do praktycznego słownika politycznego. Oznacza to, że w dalszym ciągu są one wyznacznikiem działań w środowisku międzynarodowym oraz w sferze polityki wewnętrznej. Jest to podstawa dla dalszego pogłębiania badań nad teoretycznymi aspektami interesu narodowego czy racji stanu.

\section{Bibliografia}

Arystoteles, Polityka, Wyd. PWN, Warszawa 2008.

Bezpieczeństwo międzynarodowe. Teoria i praktyka, red. K. Żukrowska, M. Gracik, Wyd. SGH, Warszawa 2006.

Buchner W., Wojna i konkwista. Hiszpańska myśl polityczna Złotego Wieku, Wyd. OMP, Kraków 2007.

Cooperative Security. Reducing Third World Wars, red. I. W. Zartman, V. A. Kremenyuk Seracuse Unversity Press, Seracuse New York 1995.

Dahl R., Stinebrickner B., Wspótczesna analiza polityczna, Wyd. Scholar, Warszawa 2007.

Furniss E. S., Snyder R. C., An Introduction to American Foreign Policy, Rinehard, New York 1955.

Guicciardini F., The History of Italy, Princeton University Press, Princeton 1984.

Informacja Ministra Spraw Zagranicznych nt. polityki zagranicznej RP w 2008 r. (wersja nie oparta na stenogramie sejmowym), http://www.msz.gov.pl/files/ExposeMinistraSikorskiego.doc.

Jabłoński A. W., Sobkowiak L., Studia z teorii polityki, t. 1, Wyd. UW, Wrocław 1998.

Kukułka J., Zaspokajanie potrzeb i rozwiqzywanie konfliktów w stosunkach międzynarodowych, w: Stosunki międzynarodowe. Geneza, struktura, dynamika, red. E. Haliżak, R. Kuźniar, Wyd. WUW, Warszawa 2006.

Kukułka J., Problemy teorii stosunków międzynarodowych, Wyd. PWN, Warszawa 1978.

Kuźniar R., Bezpieczeństwo w stosunkach międzynarodowych, w: Stosunki międzynarodowe. Geneza, struktura, dynamika, red. E. Haliżak, R. Kuźniar, Wyd. WUW, Warszawa 2006.

Lukes S., Władza i panowanie, w: Socjologia. Lektury, red. P. Sztompka, M. Kucia, Wyd. Znak, Kraków 2007.

Lukes S., Władza: poglad radykalny, „Poznańskie Studia z Filozofii Humanistyki” 1997, t. 4 (17).

Machiavelli N., Ksiqżę, Wyd. Zielona Sowa, Kraków 2006.

Machiavelli N., Rozważania, w: Wybór pism, Wyd. PIW, Warszawa 1972.

Malarczyk J., ,, Racja stanu” w ujęciu Giovanniego Botero, w: Problemy teorii i filozofii prawa, red. J. Malarczyk, Wyd. KUL, Lublin 1985.

March J. C., Preferences, Power and Democracy, w: Power, Inequality and Democratic Politics, red. I. Shapiro, G. Reeher, Westview Press, Boulder, CO - London 1988.

Modelski G., A Theory of Foreign Policy, Praeger, London 1962.

Parent J. M., Machiavelli's Missing Romulus and the Murderous Intent of The Prince, „History of Political Thought" 2005, nr 4 (vol. XXVI).

Pietraś Z. J., Racja stanu w polityce zagranicznej państwa, „Studia Nauk Politycznych” 1986, nr 5.

Popiuk-Rysinska I., Uczestnicy stosunków międzynarodowych, ich interesy i oddziatywania, w: Stosunki międzynarodowe. Geneza, struktura, dynamika, red. E. Haliżak, R. Kuźniar, Wyd. WUW, Warszawa 2006.

Power, Inequality and Democratic Politics, red. I. Shapiro, G. Reeher, Westview Press, Boulder, CO - London 1988.

Problemy teorii i filozofii prawa, red. J. Malarczyk, Wyd. KUL, Lublin 1985.

Rykiel Z., Podstawy geografii politycznej, Wyd. PWE, Warszawa 2006.

Rzegocki A., Racja stanu a polska tradycja myślenia o polityce, Wyd. OMP, Kraków 2008.

Stownik wyrazów obcych, Wyd. PWN, Warszawa 1995.

Sobkowiak L., Konflikt polityczny - analiza pojęcia, w: A. W. Jabłoński, L. Sobkowiak, Studia z teorii polityki, t. 1, Wyd. UW, Wrocław 1998.

Socjologia. Lektury, red. P. Sztompka, M. Kucia, Wyd. Znak, Kraków 2007.

Stosunki międzynarodowe. Geneza, struktura, dynamika, red. E. Haliżak, R. Kuźniar, Wyd. WUW, Warszawa 2006.

Taylor P. J., Flint C., Political Geography, Pearson Education Lim., Edinburgh 2000. 
Tratado de la religión y virtudes que debetener el Príncipe christiano para gobernar y conservar sus Estados, contra lo que Nicolás Maquiavelo y los políticos de ese tiempo enseñan, Madrid 1595, w: W. Buchner, Wojna i konkwista. Hiszpańska myśl polityczna Złotego Wieku, Wyd. OMP, Kraków 2007.

Udalov V., National Interests and Conflict Reduction, w: Cooperative Security. Reducing Third World Wars, red. I. W. Zartman, V. A. Kremenyuk, Seracuse Unversity Press, Seracuse New York 1995.

Żukrowska K., Pojęcie bezpieczeństwa i jego ewolucja, w: Bezpieczeństwo międzynarodowe. Teoria i praktyka, red. K. Żukrowska, M. Grącik, Wyd. SGH, Warszawa 2006.

\section{On the national interest or raison d'etat - theoretical considerations}

\section{Summary}

The concepts of national interest or raison d'etat continue to be fundamental elements in the foreign policies of states. Making direct reference to these concepts is crucial for making the arguments employed in political discussions efficient. The paper presents theoretical considerations on the issue of raison d'etat or national interest. It attempts to distinguish between the meanings of these two concepts, presents the changes in how they have been understood and tries to approach them theoretically. It also refers to how the raison d'etat and national interest are understood by N. Machiavelli, C. Le Bret and a range of contemporary authors.

The theoretical approach to national interest makes use of V. Udalov's theory, which discusses this concept as understood by researchers from the two opposing blocs at the time of the Cold War - the USA and the USSR. The paper also refers to the concept of interest in the context of international relations. 